Check for updates

Cite this: Food Funct., 2018, 9, 149

\section{Profiling polyphenol composition by HPLC-DAD-ESI/MSn and the antibacterial activity of infusion preparations obtained from four medicinal plants $\dagger$}

\author{
Borhane E. C. Ziani, a,b,c Lillian Barros, (D) *a Ali Z. Boumehira, ${ }^{\mathrm{b}}$ Khaldoun Bachari, ${ }^{\mathrm{b}}$ \\ Sandrina A. Heleno, (D) ${ }^{a}$ Maria Jose Alves (D) ${ }^{a}$ and Isabel C. F. R. Ferreira (D) $\star^{a}$
}

Received 24th August 2017, Accepted 18th October 2017

DOI: $10.1039 / c 7 f \circ 01315 a$

rsc.li/food-function

\begin{abstract}
The infusions of Thymus pallescens Noë, Saccocalyx satureioides Coss. et Dur., Ptychotis verticillata Briq. and Limoniastrum guyonianum Boiss. have been used as medicinal remedies for many diseases in Algerian folk medicine. These species have also been well documented as rich sources of phytochemicals, such as phenolic compounds with wide diversified chemical structures, which exhibit far-ranging biological activities. Thus, the phenolic compound profile of the aqueous extracts, obtained by infusing, of the mentioned species was obtained by HPLC-DAD-ESI/MS, and their antibacterial activity was evaluated against clinical isolates. Several phenolic acids were identified and quantified, particularly caffeic acid derivatives along with glycosylated flavonoids. T. pallescens and S. satureioides contain 13 phenolic compounds, where rosmarinic acid was the most abundant phenolic acid present, while L. guyonianum presented myricetin-3-O-glucoside and myricetin-O-rhamnoside as the main compounds among the eight detected molecules. $P$. verticillata presented a profile of ten phenolic compounds, where 5-O-caffeoylquinic acid was the most abundant phenolic acid, followed by the flavone luteolin-3-O-glucoside. The antibacterial activity of the infusions ranged between 2.5 and $20 \mathrm{mg} \mathrm{mL}^{-1}$ (MIC values), and L. guyonianum showed the highest activity against all of the tested bacteria, Staphylococcus aureus and Pseudomonas aeruginosa being the most sensitive and resistant strains, respectively. Thus, the studied plant species are sources of natural antibacterial substances that can be used to fight against pathogenic microorganisms.
\end{abstract}

\section{Introduction}

Phenolic compounds are generally part of a complex mixture isolated from plants and other matrices of biological origin., They are interesting candidates for the discovery of new antimicrobial agents to be loaded into or coated onto biomaterials. ${ }^{3,4}$ Consequently, it is essential to identify and measure all of the bioactive constituents of medicinal plants in order to ensure the reliability and repeatability of biological research as well as to enhance the quality control over the pharmacological benefits and/or hazards. ${ }^{5,6}$ Liquid chromatography coupled with

\footnotetext{
${ }^{a}$ Centro de Investigacão de Montanha (CIMO), Instituto Politécnico de Bragança, Campus de Santa Apolónia, 5300-253 Bragança, Portugal. E-mail: iferreira@ipb.pt, lillian@ipb.pt; Fax: +351-273-325405; Tel: +351-273-303219, +351-273-303285 ${ }^{b}$ Centre de Recherche Scientifique et Technique en Analyses Physico-Chimiques CRAPC-Bouismail-Tipaza, Algeria

${ }^{c}$ Département de Technologie Alimentaire et Nutrition Humaine,

Ecole nationale Supérieure Agronomique ENSA-Alger, Algeria

$\dagger$ Electronic supplementary information (ESI) available. See DOI: 10.1039/ c7fo01315a
}

different detectors, such as a diode array detector (DAD) and a mass spectrometer (MS), plays a prominent role as an analytical tool for detecting and identifying active and/or reactive metabolites. ${ }^{7,8}$ MS detection not only allows one to determine natural compounds' chemical structures, but also offers excellent sensitivity with sufficient precision and selectivity within a reasonable time, playing an important role in the analysis of phenolic compounds (e.g. flavonoids, phenolic acids and others). ${ }^{7,9-11}$

Antibiotic resistance is a serious and growing phenomenon in contemporary medicine and has emerged as one of the preeminent public health concerns in the 21st century. ${ }^{4,12}$ Most pathogenic bacteria have developed resistance to modern antibiotics, as a result of which we are observing multi-drug resistance among bacterial strains. ${ }^{4,13}$ Herbal medicine has been assumed to be an effective alternative to resolve this problem due to the bioactivities of herbs and many studies have been conducted across the globe to prove the antimicrobial efficiency and/or properties of several plants. ${ }^{3,14,15}$

Algerian medicinal plants contain a great number of bioactive compounds with therapeutic effects, ${ }^{16-18}$ and have been used since ancient times as herbal remedies. ${ }^{19,20}$ However, the phyto- 
chemical constituents of many of these species are still unknown. ${ }^{16,21}$ Thymus pallescens Noë, Saccocalyx satureioides Coss. et Dur., Ptychotis verticillata Briq and Limoniastrum guyonianum Boiss. are some examples of unexplored medicinal plants from Algeria. T. pallescens (Lamiaceae family) is an endemic plant to the northern region of Algeria, widely used for its antitussive, antiseptic, expectorant, anti-helmintic and antispasmodic properties. ${ }^{22}$ While, $S$. satureioides, also from the Lamiaceae family, is an aromatic shrub (20-100 cm). This endemic plant is normally grown in septentrional Sahara, Algeria. ${ }^{23,24}$ In folk medicine, the aerial parts are commonly used in water preparations (infusions and decoctions) for the treatments of gastric disorders and spasms, ${ }^{25}$ as well as for diabetes. ${ }^{26}$ The antimicrobial properties of its essential oils have been previously studied, ${ }^{25,27,28}$ nonetheless, the polar extracts have been less explored. Ptychotis verticillata Briq (Apiaceae family), also known as Ammoides verticillata Briq or Ptychotis ammoides Koch. and commonly named Nûnkha, ${ }^{29,30}$ is an aromatic herbaceous species (10-35 cm tall), endemic to northwestern Algeria and used for its culinary and medicinal properties as a febrifuge, antispasmodic, antiseptic and antidiabetic, especially in decoctions and infusions. ${ }^{31,32}$ Moreover, the infusions and ethanolic extracts have been reported to have a wide diversity of polyphenols (flavonoids, saponins, and tannins), while its essential oils are mainly characterized by the presence of thymol and carvacrol. ${ }^{33}$ L. guyonianum (Plumbaginaceae family) is a medicinal halophyte species endemic to the north of Africa; the infusion of its leaves and galls are traditionally used as an anti-dysenteric against infectious diseases or parasites responsible for painful and bloody diarrhea. ${ }^{34}$ Recent studies performed by Ziani et al. ${ }^{16}$ and Krifa et $a .^{35}$ demonstrated the antioxidant and antitumor potential of this plant.

To the best of the authors' knowledge, the phytochemical analysis of $T$. pallescens, $S$. satureioides and $P$. verticillata has not been previously reported. The chemical characterization and simultaneous analysis of the most prominent compounds are therefore necessary to clearly understand the biological properties of these plants. The infusion preparations of these four medicinal plant species were chosen to continue a previous study of the authors, ${ }^{16}$ where their antioxidant and cytotoxic properties were reported and different hydrophilic bioactive compounds were also quantified spectrophotometrically. Therefore, the aim of the present work was to identify those bioactive compounds by using HPLC-DAD-ESI/MSn. Furthermore, the antibacterial activity of the infusions was also tested against six Gram-negative and four Gram-positive multi-resistant bacterial strains.

\section{Materials and methods}

\subsection{Plant material}

The aerial parts of the four species (Thymus pallescens Noë, Saccocalyx satureioides Coss. et Dur., Limoniastrum guyonianum Boiss. and Ptychotis verticillata Briq) were harvested from some semi-arid and arid areas in Algeria between April and May
2014 as described in a previous study, ${ }^{16}$ taking into account local consumers' criteria for the seasoning use of these species and the optimal growth stage and gathering period. A voucher specimen of each species was deposited in the herbarium of the Department of Botany of the National Superior School of Agronomy (ENSA), where the taxonomic criteria of the authors $^{30,36}$ were used for botanical identification. After 40 days of shade-drying in the dark, all of the samples were ground for all of the subsequent analyses.

For the infusion preparation, $1 \mathrm{~g}$ of the plant material was added to $200 \mathrm{~mL}$ of boiling distilled water and left to infuse at room temperature for $5 \mathrm{~min}$, and then filtered through Whatman paper. The obtained infusions were frozen at $-20{ }^{\circ} \mathrm{C}$ and lyophilized for further analyses.

\subsection{Standards and reagents}

Acetonitrile and methanol HPLC-grade and formic acids were purchased from Fisher Scientific (Lisbon, Portugal). Phenolic compound standards were obtained from Extrasynthese (Genay, France) and their purities were above 97\%, as determined by HPLC-DAD analysis and stock solutions of these compounds (1 $\mathrm{mg} \mathrm{mL}^{-1}$ ) were prepared in methanol/water $(20: 80, \mathrm{v} / \mathrm{v})$. The culture media Mueller-Hinton broth (MHB) and tryptic soy broth (TSB) as well as blood agar with $7 \%$ sheep blood and MacConkey agar plates were obtained from Biomerieux (Marcyl'Etoile, France). The dye $p$-iodonitrotetrazolium chloride (INT) was purchased from Sigma-Aldrich (St Louis, MO, USA) and was used as a microbial growth indicator. Water was treated using the Milli-Q water purification system (TGI Pure WaterSystems, Greenville, SC, USA).

\subsection{Phenolic compound characterization by HPLC-DAD-ESI/ MSn}

For the LC/MS analysis, lyophilized infusion extracts were dissolved in water at a concentration of $10 \mathrm{mg} \mathrm{mL}^{-1}$ and filtered through a $0.22 \mu \mathrm{m}$ disposable LC filter disk prior to the analysis. Spectral UV-Vis data from all peaks were collected in the range of 240-600 $\mathrm{nm}$, and chromatograms were recorded at 370,330 and $280 \mathrm{~nm}$ for phenolic compound analysis. The HPLC-DAD-ESI/MSn (Dionex Ultimate 3000 UPLC) consisted of a diode array detector (DAD) connected to a Linear Ion Trap LTQ XL mass spectrometer (Thermo Scientific, San Jose, CA, USA), following a procedure previously reported by the authors. ${ }^{37}$ Chromatographic separation was performed using a Waters Spherisorb S3ODS-2 C18 automated column (3 $\mu \mathrm{m}$, $4.6 \times 150 \mathrm{~mm}$, Waters, Milford, MA, USA) and the mass detection was performed using ESI, operating in negative mode. An Xcalibur®data system (ThermoFinnigan, San Jose, CA, USA) was used for data acquisition.

Phenolic compound identification was achieved by comparing retention times and UV-vis and mass spectra with those of available standard compounds. Otherwise, the available data reported in the literature were applied to identify the compounds. The quantification of these compounds was calculated from the calibration curves $\left(2.5-100 \mu \mathrm{g} \mathrm{mL}{ }^{-1}\right)$ of each available phenolic standard or by using the most similar stan- 
dard available. The results were expressed as mean values \pm standard deviations (SD), in $\mathrm{mg}^{-1}$ of lyophilized infusion extract.

\subsection{Evaluation of the antibacterial activity}

2.4.1. Microorganisms and culture conditions. The tested bacterial strains were clinical isolates obtained from patients hospitalized in the Local Health Unit of Bragança and Hospital Centre of Trás-os-Montes and Alto-Douro, Vila Real, northeast of Portugal. Six Gram-negative bacteria: Morganella morganii and Pseudomonas aeruginosa isolated from expectoration, Escherichia coli, extended spectrum beta-lactamase (ESBL)producing E. coli, Klebsiella pneumoniae and extended-spectrum beta-lactamase (ESBL)-producing $K$. pneumoniae isolated from urine; and four Gram-positive bacteria: Enterococcus faecalis isolated from urine, Listeria monocytogenes isolated from cerebrospinal fluid, methicillin-sensitive Staphylococcus aureus (MSSA) isolated from wound exudate, and methicillin-resistant Staphylococcus aureus (MRSA) isolated from expectoration were tested. All strains were identified and characterized regarding the antibiotic susceptibility using the MicroScan ${ }^{\circledR}$ panels automated methodology (Siemens, Medical Solutions Diagnostics Camberley, West Sacramento, CA, USA). The interpretation criteria were based on interpretive breakpoints as indicated in Clinical and Laboratory Standards Institute, ${ }^{38}$ and in the European Committee on Antimicrobial Susceptibility Testing. ${ }^{39}$ Table S1 (ESI $\dagger$ ) shows the sensitivity/resistance profiles of the different antibiotics tested for each clinical isolate.

2.4.2. Determination of the minimal inhibitory concentrations (MICs). A microdilution method and the rapid $p$-iodonitrotetrazolium chloride (INT) colorimetric assay were used to determine the minimum inhibitory concentration (MIC). ${ }^{40}$

Briefly, stock solutions of $100 \mathrm{mg} \mathrm{mL}^{-1}$ were prepared and $100 \mu \mathrm{L}$ of each stock solution $\left(100 \mathrm{mg} \mathrm{mL}^{-1}\right)$ was diluted in $400 \mu \mathrm{L}$ of $\mathrm{MHB}$ or TSB media according to bacteria requirements (making a solution of $20 \mathrm{mg} \mathrm{mL}^{-1}$ ). Then, $200 \mu \mathrm{L}$ of this extract solution was then added to the first well of a microplate (96-well microplate) and $100 \mu \mathrm{L}$ from the first well were pipetted to other wells containing $100 \mu \mathrm{L}$ of media making successive dilutions.

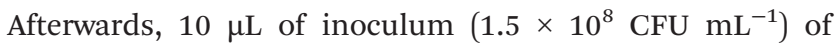
fresh overnight cultures of bacteria was added to all of the wells containing the test concentrations in the range of 20 to $0.156 \mathrm{mg} \mathrm{mL} \mathrm{m}^{-1}$. Three negative controls were prepared (one with $\mathrm{MHB} / \mathrm{TSB}$, another one with the extract, and the third one with the medium, inoculum and antibiotic).

The MIC of the samples was determined after adding INT $\left(0.2 \mathrm{mg} \mathrm{mL}{ }^{-1}, 40 \mu \mathrm{L}\right)$ and after incubation at $37^{\circ} \mathrm{C}$ in an oven (Jouan, Berlin, Germany) for 30 min where the viable microorganisms reduced the yellow dye to pink. The MIC was defined as the lowest extract concentration that prevented this change and exhibited the complete inhibition of bacterial growth.

\subsection{Statistical analysis}

Three repetitions of each sample and triplicates of the infusion preparations were used in each assay. In order to deter- mine the significant difference among samples, a Student's $t$-test (with $p=0.05$, significant differences between samples) was applied (IBM SPSS Statistics for Windows, version 23.0, IBM Corp., Armonk, New York, USA).

\section{Results and discussion}

\subsection{HPLC-DAD-ESI/MSn analysis of phenolic compounds}

The HPLC-DAD-ESI/MSn chromatographic profiles of the studied plants are shown in Fig. 1 and 2. Tables 1-3 list all of the characterized metabolites obtained by the chromatographic analysis.

Regarding the phenolic composition of Thymus pallescens and Saccocalyx satureioides, as both species belong to the Lamiaceae family, the profiles were very similar to other species belonging to this family. ${ }^{41-43}$ Thirteen compounds (six phenolic acid derivatives and seven flavonoids) were identified in both species, based on their chromatographic behavior and mass spectra, in comparison with the literature. Table 1 summarizes the identified compounds, their retention times and $\mathrm{m} / \mathrm{z}$ values for the parent ion and fragment ions. Both samples presented flavonol derivatives (quercetin, kaempferol glycoside derivatives), flavone derivatives (apigenin and luteolin glycoside derivatives) and phenolic acid derivatives, mainly caffeic acid derivatives, such as caffeic acid dimers, trimers, and tetramers (dimers of rosmarinic acid). To the best of the authors' knowledge, this is the first report regarding the phenolic composition of these two species.

Compounds 1, 5, 7, 8 and 12 were identified as 5-O-caffeoylquinic acid, quercetin-3-O-glucoside, luteolin-7-O-rutinoside, luteolin-7-O-glucuronide and rosmarinic acid, respectively, according to their DAD spectra, mass characteristics and retention times when compared with commercial standards. With the exception of compounds 1 and 5, which were only present in $T$. pallescens and compound 4 that was only present in $S$. satureioides, the other compounds were found in both samples.

Compounds 4, 9, 11, 13, 15 and 16 were identified as caffeic acid derivatives. Compound $4\left([\mathrm{M}-\mathrm{H}]^{-}\right.$at $\left.m / z 521\right)$ fragmented at $\mathrm{m} / \mathrm{z} 359$ (rosmarinic acid, loss of -162 mu, hexoside moiety), which allowed its identification as rosmarinic acid hexoside. Compound $9\left([\mathrm{M}-\mathrm{H}]^{-}\right.$at $m / z$ 719) released a main $\mathrm{MS}^{2}$ fragment at $m / z 359\left([\mathrm{M}-2 \mathrm{H}]^{2-}\right.$, rosmarinic acid), allowing its identification as sagerinic acid. ${ }^{44}$ Compounds 15 and $16\left([\mathrm{M}-\mathrm{H}]^{-}\right.$at $\left.m / z 537\right)$ revealed a similar UV spectrum and fragmentation pattern, being identified as a caffeic acid trimer, lithospermic acid A, taking into account literature findings. ${ }^{44-47}$ Compound $11\left([\mathrm{M}-\mathrm{H}]^{-}\right.$at $m / z$ 555) was tentatively assigned to salvianolic acid $\mathrm{K}$, due to a similar fragmentation pattern described by Hauck et al. ${ }^{48}$

The remaining molecules (peaks 2, 3, 6, 10, 13 and 14) correspond to flavonoid derivatives. Compound $2\left([\mathrm{M}-\mathrm{H}]^{-}\right.$at $m / z 593)$ released the $\mathrm{MS}^{2}$ fragment ions at $m / z 473$ and 383 (loss of 120 and $90 \mathrm{mu}$ characteristic of $C$-hexosyl flavones) and at $\mathrm{m} / \mathrm{z} 353$ corresponding to apigenin aglycone (apigenin + 


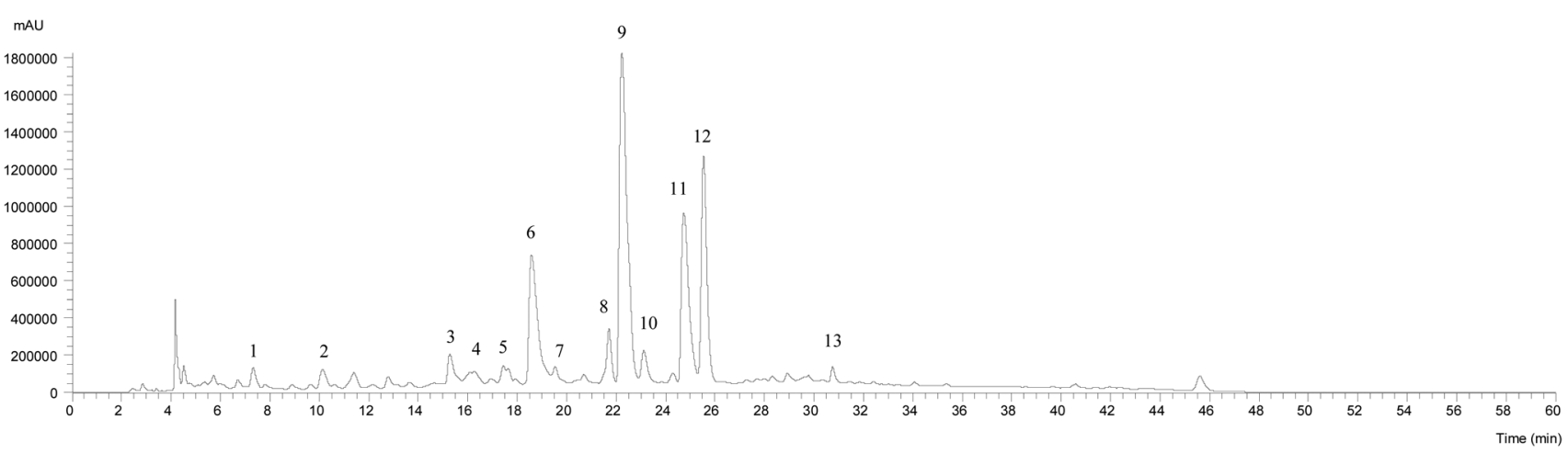

A

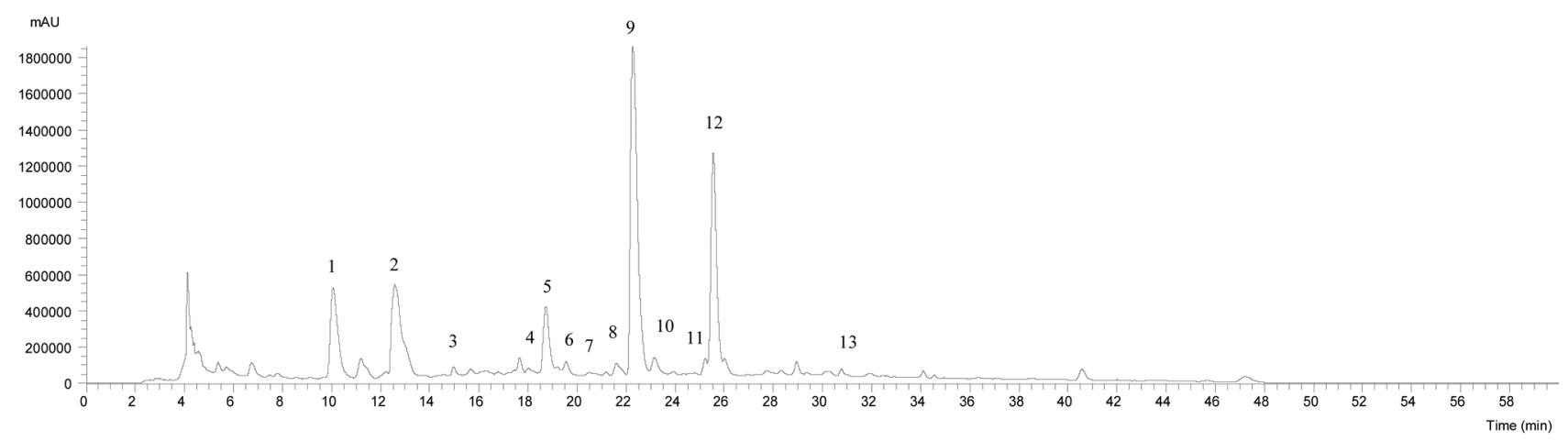

B

Fig. 1 HPLC-DAD-ESI/MSn phenolic profile of Thymus pallescens (A) and Saccocalyx satureioides (B) infusions, recorded at $280 \mathrm{~nm}$.

$83 \mathrm{mu}$, bearing some sugar residues), ${ }^{49}$ which allowed the identification of this compound as apigenin- $C$-hexoside $C$-hexoside. Thus, this compound was tentatively identified as apigenin-6,8- $C$-diglucoside. Compounds 3 and 6 presented a UV spectrum characteristic of luteolin $\left(\lambda_{\max }\right.$ at $\left.350 \mathrm{~nm}\right)$ and the same pseudomolecular ion $[\mathrm{M}-\mathrm{H}]^{-}$at $\mathrm{m} / \mathrm{z}$ 637, releasing two fragments at $\mathrm{m} / \mathrm{z} 461$ and 285 ([M $-176-176]^{-}$, loss of two glucuronyl moieties), being identified as luteolin-O-diglucuronide. Similar findings were taken into account to identify compounds 13 and 14, which were assigned to apigenin$O$-glucuronide and kaemferol-O-glucuronide, respectively. Compound 3 was only detected in $S$. satureioides, while compound 6 was identified in T. pallescens. Finally, compound 10 $\left([\mathrm{M}-\mathrm{H}]^{-}\right.$at $m / z$ 549), releasing $\mathrm{MS}^{2}$ fragments at $m / z 301$ ([M $-\mathrm{H}-162-86]^{-}$, loss of a malonylhexoside moiety) was assigned to quercetin- $O$-malonylhexoside, being only present in $S$. satureioides. Rosmarinic acid was the most abundant phenolic acid present in both samples, while luteolin-7-Oglucuronide was the most abundant flavonoid present in T. pallescens and apigenin-6,8-C-dihexoside was predominant in $S$. satureioides.

In the case of $L$. guyonianum infusion, only flavonol glycoside derivatives were detected, related to myricetin $\left(\lambda_{\max }\right.$ around
$354 \mathrm{~nm}$, an $\mathrm{MS}^{2}$ fragment at $m / z$ 317). They presented $\mathrm{MS}^{2}$ fragments corresponding to distinct losses of glucuronyl (-176 mu), glucosyl (-162 mu) and rhamnosyl (-146 mu) moieties, and an elution order coherent with the type of substituent sugar, according to their expected polarity, being assigned to myricetin-O-glucuronide (peak $2^{\mathrm{Lg}}$ ), myricetin-3-O-glucoside (peak $3^{\mathrm{Lg}}$, positively identified with the commercial standards), and myricetin-O-rhamnoside (peak $5^{\mathrm{Lg}}$ ), respectively. Myricetin and its derivatives have been previously described in Limoniastrum feei (Girard) Batt from Algeria ${ }^{50}$ as myricetin-3-Obeta-galactopyranoside and myricetin-3-O-alpha-rhamnopyranoside. Taking into account the position and nature of the sugar moieties, peaks $2^{\mathrm{Lg}}$ and $5^{\mathrm{Lg}}$ were assumed to be myricetin-3-Oglucuronide and myricetin-3-O-rhamnoside, respectively.

Furthermore, compound $1^{\mathrm{Lg}}$ was identified as a hexosyl derivative of myricetin that also appeared to be attached to a gallic acid moiety (-152 mu), yielding a deprotonated ion at $\mathrm{m} / \mathrm{z}$ 631, which consisted of a myricetin-hexosyl-gallate. Compounds $4^{\mathrm{Lg}}, 6^{\mathrm{Lg}}$ and $8^{\mathrm{Lg}}$ presented the same pseudomolecular ion $[\mathrm{M}-\mathrm{H}]^{-}$at $m / z 505$, releasing an $\mathrm{MS}^{2}$ fragment at $\mathrm{m} / \mathrm{z} 317$ (myricetin; [M - H $-42-162]^{-}$, loss of an acetylhexoside moiety), being assigned to myricetin- $O$-acetylhexoside. No further identification was possible to obtain for peak $7^{\text {Lg }}$ 


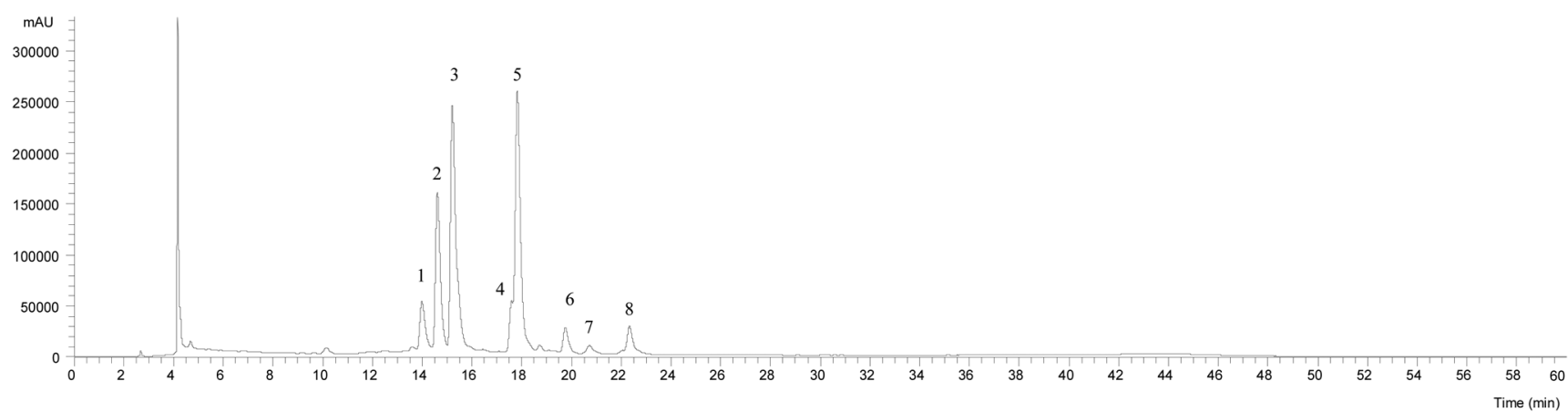

$\mathbf{A}$

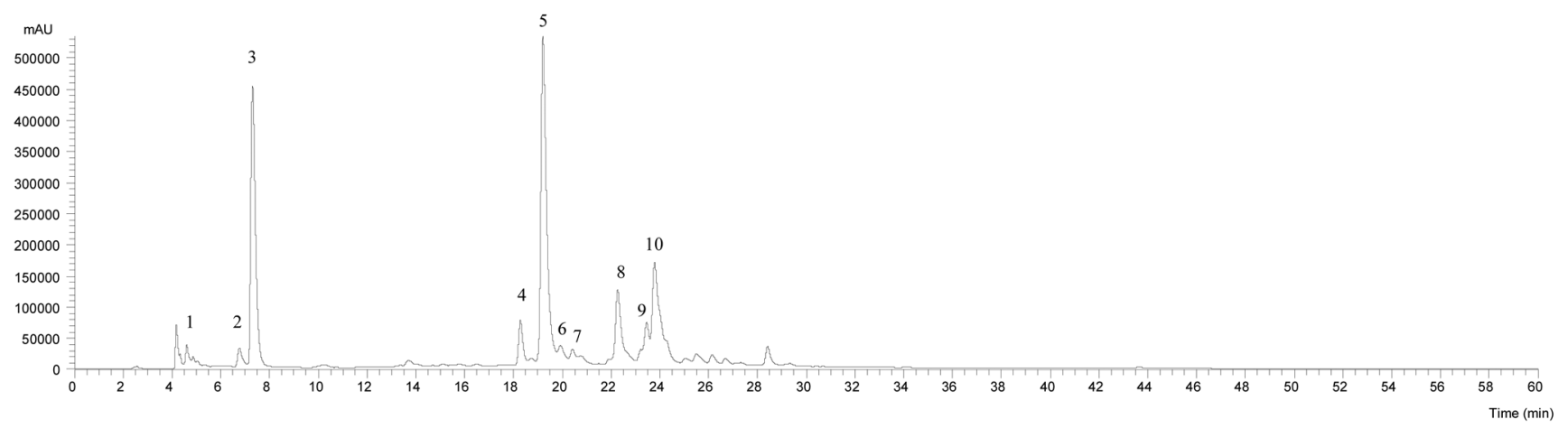

B

Fig. 2 HPLC-DAD-ESI/MSn phenolic profile of Limoniastrum guyonianum (A) and Ptychotis verticillata (B) infusions, recorded at $370 \mathrm{~nm}$.

Table 1 Retention time $\left(R_{\mathrm{t}}\right)$, wavelengths of maximum absorption in the visible region $\left(\lambda_{\max }\right)$, mass spectral data, tentative identification and quantification of phenolic compounds in Thymus pallescens and Saccocalyx satureioides infusions

\begin{tabular}{|c|c|c|c|c|c|c|c|c|}
\hline \multirow[b]{2}{*}{ Peak } & \multirow[b]{2}{*}{$\begin{array}{l}R_{\mathrm{t}} \\
(\mathrm{min})\end{array}$} & \multirow[b]{2}{*}{$\begin{array}{l}\lambda_{\max } \\
(\mathrm{nm})\end{array}$} & \multirow[b]{2}{*}{$\begin{array}{l}{[\mathrm{M}-\mathbf{H}]^{-}} \\
(\mathrm{m} / \mathrm{z})\end{array}$} & \multirow[b]{2}{*}{$\operatorname{MS}^{2}(m / z)$} & \multirow[b]{2}{*}{$\begin{array}{l}\text { Tentative } \\
\text { identification }\end{array}$} & \multicolumn{2}{|l|}{$\begin{array}{l}\text { Quantification } \\
{\text { (mg } \mathrm{g}^{-1} \text { extract) }}\end{array}$} & \multirow[b]{2}{*}{$\begin{array}{l}t \text {-Student's } \\
\text { test } p \text {-value }\end{array}$} \\
\hline & & & & & & Thymus pallescens & $\begin{array}{l}\text { Saccocalyx } \\
\text { satureioides }\end{array}$ & \\
\hline 1 & 7.32 & 326 & 353 & 191(100), 179(5), 161(3), 135(3) & 5-O-Caffeoylquinic acid & $2.59 \pm 0.04$ & nd & - \\
\hline 2 & 10.13 & 327 & 593 & $\begin{array}{l}473(3), 383(15), 353(2) \\
311(3), 297(36)\end{array}$ & Apigenin-6,8-C-dihexoside & $2.54 \pm 0.01$ & $12.2 \pm 0.4$ & $<0.001$ \\
\hline 3 & 12.57 & 336 & 637 & $461(100), 285(7)$ & Luteolin-O-diglucuronide & nd & $5.0 \pm 0.2$ & - \\
\hline 4 & 14.55 & 320 & 521 & $\begin{array}{l}359(100), 197(4), 179(4), \\
161(3), 135(2)\end{array}$ & Rosmarinic acid hexoside & nd & $1.68 \pm 0.08$ & - \\
\hline 5 & 15.28 & 342 & 477 & $301(100)$ & Quercetin-3-O-glucoside & $2.17 \pm 0.07$ & nd & - \\
\hline 6 & 16.1 & 334 & 637 & $461(100), 285(20)$ & Luteolin-O-diglucuronide & $1.23 \pm 0.01$ & nd & - \\
\hline 7 & 17.94 & 343 & 593 & $285(100)$ & Luteolin-7-O-rutinoside & $1.30 \pm 0.01$ & $1.22 \pm 0.01$ & $<0.001$ \\
\hline 8 & 18.58 & 347 & 461 & $285(100)$ & Luteolin-7-O-glucuronide & $11.5 \pm 0.3$ & $5.2 \pm 0.2$ & $<0.001$ \\
\hline 9 & 19.53 & 283,328 & 719 & $\begin{array}{l}539(25), 521(20), 359(100), \\
297(3), 179(36), 161(2), 135(3)\end{array}$ & Sagerinic acid & $2.78 \pm 0.07$ & $2.39 \pm 0.01$ & $<0.001$ \\
\hline 10 & 20.5 & 334 & 549 & 505(30), 463(100), 301(20) & Quercetin-O-malonyhexoside & nd & $1.11 \pm 0.01$ & - \\
\hline 11 & 21.71 & 288,323 & 555 & $\begin{array}{l}537(5), 511(8), 493(10), 311(100), \\
197(19), 179(3), 161(3), 135(12)\end{array}$ & Salvianolic acid $\mathrm{K}$ & $5.72 \pm 0.01$ & $2.72 \pm 0.02$ & $<0.001$ \\
\hline 12 & 22.24 & 328 & 359 & $197(27), 179(37), 161(100), 135(2)$ & Rosmarinic acid & $43.1 \pm 0.8$ & $50.1 \pm 0.4$ & $<0.001$ \\
\hline 13 & 23.11 & 335 & 445 & $269(100)$ & Apigenin-O-glucuronide & $4.56 \pm 0.05$ & $3.3 \pm 0.1$ & $<0.001$ \\
\hline 14 & 24.74 & 340 & 461 & $285(100)$ & Kaempferol-O-glucuronide & $29.1 \pm 0.5$ & $1.35 \pm 0.03$ & $<0.001$ \\
\hline 15 & 25.54 & 329 & 537 & $\begin{array}{l}\text { 493(8), 359(100), 313(11), 295(4), } \\
197(2), 179(3), 161(2)\end{array}$ & Lithospermic acid A isomer I & $20.9 \pm 0.9$ & $21.69 \pm 0.02$ & 0.107 \\
\hline \multirow[t]{4}{*}{16} & 30.76 & 329 & 537 & $\begin{array}{l}\text { 493(9), 359(100), 313(9), 295(3), } \\
197(3), 179(3), 161(4)\end{array}$ & Lithospermic acid A isomer II & $2.7 \pm 0.1$ & $2.22 \pm 0.03$ & $<0.001$ \\
\hline & & & & & Total phenolic acid & $78 \pm 2$ & $80.8 \pm 0.5$ & 0.020 \\
\hline & & & & & Total flavonoids & $52.4 \pm 0.9$ & $29.3 \pm 0.9$ & $<0.001$ \\
\hline & & & & & Total phenolic compounds & $130 \pm 3$ & $110 \pm 1$ & $<0.001$ \\
\hline
\end{tabular}


Table 2 Retention time $\left(R_{\mathrm{t}}\right)$, wavelengths of maximum absorption in the visible region $\left(\lambda_{\max }\right)$, mass spectral data, tentative identification and quantification of phenolic compounds in Limoniastrum guyonianum infusion

\begin{tabular}{|c|c|c|c|c|c|c|}
\hline Peak & $R_{\mathrm{t}}(\min )$ & $\lambda_{\max }(\mathrm{nm})$ & {$[\mathrm{M}-\mathrm{H}]^{-}(m / z)$} & $\operatorname{MS}^{2}(m / z)$ & Tentative identification & $\begin{array}{l}\text { Quantification } \\
\text { (mg g }{ }^{-1} \text { extract) }\end{array}$ \\
\hline $1^{\mathrm{Lg}}$ & 13.99 & 353 & 631 & $479(5), 317(100)$ & Myricetin-hexosyl-gallate & $5.73 \pm 0.05$ \\
\hline $2^{\operatorname{Lg}}$ & 14.61 & 353 & 493 & $317(100)$ & Myricetin-3-O-glucuronide & $6.90 \pm 0.08$ \\
\hline $3^{\mathrm{Lg}}$ & 15.21 & 356 & 479 & $317(100)$ & Myricetin-3-O-glucoside & $8.2 \pm 0.2$ \\
\hline $4^{\mathrm{Lg}}$ & 17.5 & 354 & 535 & $317(100)$ & Myricetin- $O$-acetylglucoronide & $5.41 \pm 0.02$ \\
\hline $5^{\mathrm{Lg}}$ & 17.83 & 349 & 463 & $317(100)$ & Myricetin-3-O-rhamnoside & $8.12 \pm 0.05$ \\
\hline $6^{\mathrm{Lg}}$ & 19.75 & 355 & 535 & $317(100)$ & Myricetin- $O$-acetylglucoronide & $5.36 \pm 0.06$ \\
\hline $7^{\mathrm{Lg}}$ & 20.72 & 352 & 659 & $493(12), 479(100), 317(51)$ & Myricetin derivative & $5.17 \pm 0.03$ \\
\hline \multirow[t]{2}{*}{$8^{\mathrm{Lg}}$} & 22.33 & 353 & 535 & $317(100)$ & Myricetin-O-acetylglucoronide & $5.36 \pm 0.01$ \\
\hline & & & & & Total phenolic compounds & $50.3 \pm 0.5$ \\
\hline
\end{tabular}

Table 3 Retention time $\left(R_{\mathrm{t}}\right)$, wavelengths of maximum absorption in the visible region $\left(\lambda_{\max }\right)$, mass spectral data, tentative identification and quantification of phenolic compounds in Ptychotis verticillata infusion

\begin{tabular}{|c|c|c|c|c|c|c|}
\hline Peak & $\begin{array}{l}R_{\mathrm{t}} \\
(\mathrm{min})\end{array}$ & $\begin{array}{l}\lambda_{\max } \\
(\mathrm{nm})\end{array}$ & $\begin{array}{l}{[\mathrm{M}-\mathrm{H}]^{-}} \\
(\mathrm{m} / \mathrm{z})\end{array}$ & $\operatorname{MS}^{2}(m / z)$ & Tentative identification & $\begin{array}{l}\text { Quantification } \\
\text { (mg g }{ }^{-1} \text { extract) }\end{array}$ \\
\hline $1^{\mathrm{Pv}}$ & 4.94 & 323 & 353 & 191(100), 179(45), 161(3), 135(8) & 3-O-Caffeoylquinic acid & $3.04 \pm 0.10$ \\
\hline $4^{\mathrm{Pv}}$ & 18.28 & 347 & 593 & $285(100)$ & Luteolin-7-O-rutinoside & $1.49 \pm 0.03$ \\
\hline $5^{\mathrm{Pv}}$ & 19.21 & 347 & 447 & $285(100)$ & Luteolin-7-O-glucoside & $5.99 \pm 0.22$ \\
\hline $6^{\mathrm{Pv}}$ & 19.93 & 347 & 609 & $285(100)$ & Kaempferol-O-dihexoside & $0.75 \pm 0.03$ \\
\hline $9^{\mathrm{Pv}}$ & 23.79 & 347 & 447 & $285(100)$ & Kaempferol-O-glucuronide & $5.44 \pm 0.32$ \\
\hline \multirow[t]{4}{*}{$10^{\mathrm{Pv}}$} & 24.2 & 337 & 489 & $285(100)$ & Kaempferol-O-acetylhexoside & $0.74 \pm 0.01$ \\
\hline & & & & & Total phenolic acid & $47.35 \pm 1.57$ \\
\hline & & & & & Total flavonoids & $18.28 \pm 0.67$ \\
\hline & & & & & Total phenolic compounds & $65.63 \pm 2.25$ \\
\hline
\end{tabular}

$\left([\mathrm{M}-\mathrm{H}]^{-}\right.$at $m / z$ 659), being assigned to a myricetin derivative. The major myricetin derivatives present in this sample were myricetin-3-O-glucoside and myricetin-O-rhamnoside, respectively.

The phenolic profile of $P$. verticillata infusion, determined by HPLC-DAD-ESI/MSn, presented three chlorogenic acids, being compounds 1,2 and $3\left([\mathrm{M}-\mathrm{H}]^{-}\right.$at $\left.\mathrm{m} / \mathrm{z} 353\right)$ identified as 3-O-caffeoylquinic acid, 4-O-caffeoylquinic acid and 5-Ocaffeoylquinic acid, respectively, according to their similar fragmentation pattern previously described by Clifford et $a l .^{51,52}$ The remaining compounds were identified as flavonols (peaks $6^{\mathrm{Pv}}, 7^{\mathrm{Pv}}, 9^{\mathrm{Pv}}$ and $10^{\mathrm{Pv}}$ ) and flavones $\left(4^{\mathrm{Pv}}, 5^{\mathrm{Pv}}\right.$ and $8^{\mathrm{Pv}}$ ). The latter compounds $4^{\mathrm{Pv}}$ (luteolin-3-O-rutinoside), $5^{\mathrm{Pv}}$ (luteolin-3-O-glucuronide) and $8^{\mathrm{Pv}}$ (apigenin-3-O-glucoside) were positively identified with commercial standards. Peak $7^{\mathrm{Pv}}$ $\left([\mathrm{M}-\mathrm{H}]^{-}\right.$at $\left.m / z 505\right)$ released two fragments, at $m / z 463(-42$, loss of a acetyl moiety) and $m / z 301(-162 \mathrm{u}$, loss of a hexosyl moiety), thus being tentatively assigned to quercetin- $O$-acetylhexoside. Compounds $6^{\mathrm{Pv}}\left([\mathrm{M}-\mathrm{H}]^{-}\right.$at $\left.m / z 609\right), 9^{\mathrm{Pv}}\left([\mathrm{M}-\mathrm{H}]^{-}\right.$ at $m / z 447)$ and $10^{\mathrm{Pv}}\left([\mathrm{M}-\mathrm{H}]^{-}\right.$at $\mathrm{m} / z$ 489) were identified as kaempferol glycosides based on their UV spectra $\left(\lambda_{\max }\right.$ around $348 \mathrm{~nm}$ ) and the production of an $\mathrm{MS}^{2}$ fragment ion at $\mathrm{m} / \mathrm{z}$ 285, and could be assumed as kaempferol-O-dihexoside, kaempferol-O-glucuronide and kaempferol- $O$-acetylhexoside, respectively. 5-O-Caffeoylquinic acid was the most abundant compound, followed by the flavone luteolin-3-O-glucoside.

\subsection{Antibacterial activity}

The search for natural antimicrobial compounds in clinical microbiology is incited by the need to thwart the increasing infectious diseases caused by multiple drug resistant (MDR) and total drug resistant (TDR) strains. ${ }^{4}$ In the biomedical field, the microbial antibiotic-resistance leads to a growing need for new, effective anti-infective materials for the prevention and delay of implant and device-associated infections. ${ }^{53}$ In the present work, the antibacterial activity of the samples was tested against ten bacteria, some of them being multiresistant. The infusion of L. guyonianum showed the highest activity against E. coli, E. coli ESBL, MRSA and MSSA (MICs $=2.5$ $\mathrm{mg} \mathrm{mL}^{-1}$ ), followed by $K$. pneumoniae, $K$. pneumoniae ESBL, E. faecalis, L. monocytogenes (MICs $=5 \mathrm{mg} \mathrm{mL}^{-1}$ ), and $P$. aeruginosa and $M$. morganii (MICs ranging between 10-20 mg $\mathrm{mL}^{-1}$ ). The infusions of $T$. pallescens and $S$. satureioides showed almost similar values and were found to be less active against $K$. pneumoniae, $K$. pneumoniae ESBL, E. faecalis, L. monocytogenes, $P$. aeruginosa and $M$. morganii strains (MICs ranging from 2.5 to $>20 \mathrm{mg} \mathrm{mL}^{-1}$ ) (Table 4). $P$. verticillata infusion showed the weakest activity against all of the bacteria presenting MIC values in the highest tested concentration or even presenting no activity at the maximum tested concentration: $20 \mathrm{mg} \mathrm{mL}{ }^{-1}$. These results showed that 
Table 4 MIC values (expressed in $\mathrm{mg} \mathrm{mL}^{-1}$ ) of Thymus pallescens, Saccocalyx satureioides, Limoniastrum guyonianum and Ptychotis verticillata infusions against six Gram-negative and four Gram-positive bacterial strains

\begin{tabular}{lcccc}
\hline Antimicrobial activity MIC values $\left(\mathrm{mg} \mathrm{mL}^{-1}\right)$ & Thymus pallescens & Saccocalyx satureioides & Limoniastrum guyonianum & Ptychotis verticillata \\
\hline Gram-negative bacteria & & & & 2.5 \\
Escherichia coli & 10 & 5 & 2.5 & 20 \\
Escherichia coli ESBL & 10 & 5 & 5 & 20 \\
Klebsiella pneumoniae & 10 & 10 & 5 & 20 \\
Klebsiella pneumoniae ESBL & 10 & 10 & 20 & $>20$ \\
Morganella morganii & 20 & 20 & & $>20$ \\
Pseudomonas aeruginosa & 20 & & 5 & 20 \\
Gram-positive bacteria & & 10 & 5 & 2.5 \\
Enterococus faecalis & 10 & 10 & 5 & 10 \\
Listeria monocytogenes & 10 & 5 & 2.5 & 10 \\
MRSA & 5 & 5 & &
\end{tabular}

MRSA, methicillin-resistant Staphylococcus aureus; MSSA, methicillin-susceptible Staphylococcus aureus; MIC, minimal inhibitory concentration; ESBL, extended-spectrum beta-lactamases.

the plant infusions can inhibit bacterial strains irrespective of their mechanisms of resistance. No significant differences were observed between the strains showing well-known mechanisms of resistance and the susceptible ones, because one-dilution differences in this kind of analysis are taken for granted.

Many research groups have gone one step further and isolated and identified the structure of flavonoids that possess antibacterial activity. The studied infusions were found to be rich sources of phenolic components that could exert antibacterial activity. For instance, flavonols and their derivatives, as they were found abundantly in the infusion of $T$. pallescens (quercetin and kaempferol) and L. guyonianum (myricetin), are characterized by a remarkable antibacterial activity against both Gram-positive and Gram-negative bacteria, such as S. aureus, Lactobacillus acidophilus, Porphyromonas gingivalis, Prevotella melaninogenica, S. epidermidis, E. coli, Proteus vulgaris, $P$. aeruginosa, Enterococcus aerogenes and Enterobacter sakazakii. ${ }^{42,54}$ Quercetin, 3-O-methylquercetin and several quercetin glycosides, ${ }^{55-59}$ and also kaempferol and its glycoside derivatives, ${ }^{55,57,60}$ were also reported to have antimicrobial activity. Other categories of compounds with known antibacterial activity are phenolic acids, such as chlorogenic, protocatechuic, $p$-coumaric, caffeic, syringic, $p$-hydroxybenzoic, ferulic, vanillic, gentisic and gallic acids, ${ }^{12}$ their derivatives, ${ }^{42}$ and flavones (e.g. apigenin and luteolin glycoside derivatives) ${ }^{12,55,56,61-65}$ isoflavones, ${ }^{66-69}$ flavanones, ${ }^{56,70}$ and other flavonol glycosides. ${ }^{56,71-74}$

To the best of the authors' knowledge, no data are available on the antibacterial activity of these plants against drug-resistant bacteria in the literature. The obtained results showed that the antibacterial activity of all of the plant infusions is moderate, especially against Gram-positive bacteria. Moreover, whilst methicillin-resistant strains usually display resistance to several drugs, no relevant differences were observed between methicillin-susceptible and -resistant strains. These data are also in agreement with earlier studies carried out on other species belonging to the genus of the studied plants. Aqueous extracts obtained from Thymus vulgaris showed antibacterial activity against many ATCC bacterial strains. ${ }^{42,75,76}$ Moreover, many solvent fractions of $L$. guyonianum from Tunisia showed antibacterial activity against several human pathogenic strains such as S. aureus, E. feacalis, E. coli, Salmonella typhi and P. aeruginosa $;^{77}$ also, the Tunisian $L$. guyonianum methanolic, chloroformic and petroleum extracts showed a potent action against $P$. aeruginosa and $S$. aureus with MIC values of 23 and $46 \mu \mathrm{g} \mathrm{mL}{ }^{-1}$ as the best values, respectively. ${ }^{78}$ Concerning the antimicrobial activity of $S$. satureioides, only the essential oil was previously studied by the authors, ${ }^{25}$ and showed strong potential against ATCC bacterial strains (Bacillus subtilis, $S$. aureus, L. monocytogenes, E. faecalis, E. coli, K. pneumoniae, Proteus mirabilis, $P$. aeruginosa and Salmonella typhimurium).

According to the results obtained from the HPLC-DAD-ESI/ MSn analysis, the appreciable antibacterial activity of the extracts against MDR strains could be explained by the wide spectrum of polyphenols identified in the infusions (previous section), which act as antimicrobial substances via different mechanisms of action (MA). In fact, many MA are ascribed to polyphenols, such as cytoplasmic membrane damage, and inhibition of nucleic acid, cell wall and cell membrane synthesis., ${ }^{3,55}$ Moreover, in addition to their direct antibacterial activity, a growing body of evidence suggests that polyphenols may interfere with some bacterial virulence factors such as enzymes, toxins and signal receptors. ${ }^{3,55,56,73}$

\section{Conclusion}

Overall, this work focuses on the determination of the phenolic compound profile as well as on the investigation of the antibacterial activity of four medicinal plant species from the Algerian flora. The identification and quantification of phenolic compounds in T. pallescens, $S$. satureioides, L. guyonianum and $P$. verticillata have been accomplished. The results indicate 
that the infusion preparation of $T$. pallescens and $S$. satureioides contained considerable amounts of rosmarinic acid, lithospermic acid A, luteolin-7-O-glucuronide and apigenin-6,8-C-dihexoside, while $L$. guyonianum was rich in myricetin derivatives (glucosides) and $P$. verticillata was rich in caffeic acid derivatives particularly 5-O-caffeoylquinic acid. The findings of this study showed that all four species exhibited a broad spectrum of antibacterial activity against clinical isolates (MIC values between 2.5 and $20 \mathrm{mg} \mathrm{mL}^{-1}$ ), which could be used as an alternative source of antibiotics. However, pharmacological testing is necessary following the isolation of the bioactive compounds. The infusions of these plants should be furthermore investigated in vivo to better understand their efficacy and medicinal properties.

\section{Conflicts of interest}

There are no conflicts to declare.

\section{Acknowledgements}

The authors are grateful to the Foundation for Science and Technology (FCT, Portugal) and FEDER under Programme PT2020 for financial support to CIMO (UID/AGR/00690/2013), S. Heleno (SFRH/BPD/101413/2014) grant and L. Barros contract. The authors are also grateful to the Interreg EspañaPortugal for financial support through the project 0377_Iberphenol_6_E.

\section{References}

1 D. Lin, M. Xiao, J. Zhao, Z. Li, B. Xing, X. Li, M. Kong, L. Li, Q. Zhang, Y. Liu, H. Chen, W. Qin, H. Wu and S. Chen, An overview of plant phenolic compounds and their importance in human nutrition and management of Type 2 Diabetes, Molecules, 2016, 21, 2-19.

2 S. Maqsood, S. Benjakul, A. Abushelaibi and A. Alam, Phenolic compounds and plant phenolic extracts as natural antioxidants in prevention of lipid oxidation in seafood : a detailed Review, Compr. Rev. Food Sci. Food Saf., 2014, 13, 1125-1140.

3 M. Wink, Modes of action of herbal medicines and plant secondary metabolites, Medicines, 2015, 251-286.

4 P. Vadhana, B. R. Singh, M. Bharadwaj and S. V. Singh, Pharmaceutical emergence of herbal antimicrobial drug resistance in clinical bacterial isolates, Pharm. Anal. Acta, 2015, 6, 434.

5 A. O. Matei, F. Gatea and G. L. Radu, Analysis of phenolic compounds in some medicinal herbs by LC - MS, J. Chromatogr. Sci., 2015, 12, 1-8.

6 P. Terpinc, C. Blaz, T. Polak, J. Hribar and T. Pozrl, LC - MS analysis of phenolic compounds and antioxidant activity of buckwheat at different stages of malting, Food Chem., 2016, 210, 9-17.
7 G. Chen, X. Li, F. Saleri and M. Guo, Analysis of flavonoids in rhamnus davurica and its antiproliferative activities, Molecules, 2016, 21, 1-14.

8 M. Tasioula-margari and E. Tsabolatidou, Extraction, separation, and identification of phenolic compounds in virgin olive oil by HPLC-DAD and HPLC-MS, Antioxidants, 2015, 4, 548-562.

9 D. Benedec, L. Vlase, I. Oniga, A. C. Mot, R. SilaghiDumitrescu, D. Hanganu, B. Tiperciuc and G. Crişan, LC-MS analysis and antioxidant activity of phenolic compounds from two indigenous species of Mentha. Note I, Farmacia, 2013, 61, 262-267.

10 W. Rached, M. Bennaceur, L. Barros, R. C. Calhelha, S. Heleno, M. J. Alves, M. Carvalho, A. M. Abderrazak and I. C. F. R. Ferreira, Detailed phytochemical characterization and bioactive properties of Myrtus nivelii, Batt \& Trab., Food Funct., 2017, 8, 3111-3119.

11 I. Jabeur, N. Martins, L. Barros, R. C. Calhelha, J. Vaz, L. Achour, C. Santos-Buelga and I. C. F. R. Ferreira, Contribution of phenolic composition to the antioxidant, anti-inflammatory and antitumor potential of Equisetum giganteum L. and Tilia platyphyllos Scop., Food Funct., 2017, 8, 975-984.

12 M. Kozyra, A. Biernasiuk and A. Malm, Natural drugs analysis of phenolic acids and antibacterial activity of extracts obtained from the flowering herbs, Acta Pol. Pharm. Drug Res., 2017, 74, 161-172.

13 P. C. Carvajal, E. Coppo, A. Di Lorenzo, D. Gozzini, F. Bracco, G. Zanoni, S. M. Nabavi, A. Marchese, C. R. Arciola and M. Daglia, Chemical characterization and in vitro antibacterial activity of Myrcianthes hallii, (O. Berg) McVaugh (Myrtaceae), a traditional plant growing in ecuador, Materials, 2016, 9, 1-14.

14 N. Amin, R. Shawahna, A. Mustafa, R. Al-ramahi, M. Kasem and A. Naser, Herbal remedies use by breast cancer patients in the West Bank of Palestine, J. Ethnopharmacol., 2016, 178, 1-8.

15 S. A. Heleno, L. Barros, A. Martins, P. Morales, V. FernandezRuiz, J. Glamoclija, M. Sokovic and I. C. F. R. Ferreira, Nutritional value, bioactive compounds, antimicrobial activity and bioaccessibility studies with wild edible mushrooms, LWT-Food Sci. Technol., 2015, 63, 799-806.

16 B. E. C. Ziani, R. C. Calhelha, J. C. M. Barreira, L. Barros, M. Hazzit and I. C. F. R. Ferreira, Bioactive properties of medicinal plants from the Algerian flora : Selecting the species with the highest potential in view of application purposes, Ind. Crops Prod., 2015, 77, 582-589.

17 A. Djeridane, M. Yousfi, B. Nadjemi, D. Boutassouna, P. Stocker and N. Vidal, Antioxidant activity of some algerian medicinal plants extracts containing phenolic compounds, Food Chem., 2006, 97, 654-660.

18 W. Rached, R. C. Calhelha, M. Bennaceur, A. Marouf, L. Barros, C. Santos-buelga and I. C. F. R. Ferreira, Phytochemical characterization and bioactive properties of Osyris quadripartita, Salzm. ex Decne. leaves from Algeria, RCS Advances, 2016, 6, 72768-72776. 
19 L. Reguieg, Using medicinal plants in Algeria, Am. J. Food Nutr., 2011, 1, 126-127.

20 B. Benarba, Use of medicinal plants by breast cancer patients in Algeria, EXCLIJ., 2015, 14, 1164-1166.

21 F. Ramdane, M. H. Mahammed, M. D. O. Hadj, A. Chanai, R. Hammoudi, N. Hillali, H. Mesrouk, I. Bouafia and C. Bahaz, Ethnobotanical study of some medicinal plants from Hoggar, Algeria, J. Med. Plants Res., 2015, 9, 820-827.

22 M. Hazzit, A. Baaliouamer, A. R. Veríssimo, M. L. Faleiro and M. G. Miguel, Chemical composition and biological activities of Algerian Thymus oils, Food Chem., 2009, 116, 714-721.

23 P. Ozenda, in Flore du Sahara septentrional et central, CNRS, Paris, France, 3rd edn, 2004.

24 P. Quezel and S. Santa, Nouvelles flores de l'Algérie et des régions désertiques méridionales, CNRS, Paris, France, 1983, vol. T. II.

25 M. Bendahou, M. Benyoucef, A. Muselli, J. Desjobert, J. Paolini, A. Bernardini and J. Costa, Antimicrobial activity and chemical composition of Saccocalyx satureioides Coss. et Dur. Essential oil and extract obtained by microwave extraction. comparison with hydrodistillation, J. Essent. Oil Res., 2014, 20, 174-178.

26 N. Belmekki and N. Bendimerad, Antioxidant activity and phenolic content in methanol crude extracts from three Lamiaceae grown in southwestern Algeria, J. Nat. Prod. plant Resour., 2012, 2, 175-181.

27 M. M. Zerroug, H. Laouer, R. Strange and J. Nicklin, The effect of essential oil of Saccocalyx satureioides Coss. Et Dur. on the growth of and the production of solanapyrone a by Ascochyta rabiei (Pass.) Labr, Adv. Environ. Biol., 2011, 5, 501-506.

28 D. M. Biondi, M. Sari, Z. A. Ghani and G. Ruberto, Essential oil of Algerian Saccocalyx satureioides, Coss. et Durieu, Flavour Fragrance J., 2006, 21, 546-548.

29 L. Bellakhdar, La Pharmacopée Marocaine Traditionnelle. Médecine Arabe Ancienne et Savoirs Populaires, Ibis Press, Paris, 1997.

30 P. Quezel and S. Santa, in Nouvelle flore de l'Algérie et des régions désertiques méridionales, CNRS, Paris, 1963, vol. Tome II, pp. 350-1170.

31 E. O. El Mokhtar, P. Tomi, A. Bouyanzer, B. Hammouti, J. Desjobert, J. Costa and J. Paolini, Chemical composition and antioxidant activity of essential oils and solvent extracts of Ptychotis verticillata from Morocco, Food Chem. Toxicol., 2011, 49, 533-536.

32 M. Bnouham, W. Benalla, A. Asehraou and M. Berrabah, Antibacterial activity of essential oil from Ptychotis verticillata, Spatula DD, 2012, 2, 69-73.

33 O. Toubal, A. Djahoudi, C. Henchiri and M. Bouazza, Phytochemical screening and antimicrobial evaluation of the aqueous extracts of Ammoides verticillata, an Endemic Species, J. Life Sci., 2012, 6, 243-247.

$34 \mathrm{M}$. Chaieb and M. Boukhris, Flore succincte et illustrée des zones arides et sahariennes de Tunisie, Association pour la protection de la nature et de l'environnement, Sfax, 1998.
35 M. Krifa, I. Skandrani, A. Pizzi, N. Nasr, Z. Ghedira, N. Mustapha, K. Ghedira and L. Chekir-ghedira, An aqueous extract of Limoniastrum guyonianum gall induces anti-tumor effects in melanoma-injected mice via modulation of the immune response, Food Chem. Toxicol., 2014, 69, 76-85.

36 R. Maire, Flore de l'Afrique de Nord, Paul lechevalier, paris (VI), 1962, vol. VIII.

37 S. M. F. Bessada, J. C. M. Barreira, L. Barros, I. C. F. R. Ferreira and M. B. P. P. Oliveira, Phenolic profile and antioxidant activity of Coleostephus myconis (L.) Rchb.f.: An underexploited and highly disseminated species, Ind. Crops Prod., 2016, 89, 45-51.

38 CLSI, Performance Standards for Antimicrobial Susceptibility Testing, 18th Informational Supplement. CLSI Document M100-S18, 2008.

39 EUCAST, ESCMID: European Society of Clinical Microbiology and Infectious Diseases, http://www.eucast. org/ast of bacteria/ previous versions of documents/.

40 B. Svobodova, L. Barros, R. C. Calhelha, S. Heleno, M. Jose, S. Walcott, M. Bittova, V. Kuban and I. C. F. R. Ferreira, Bioactive properties and phenolic profile of Momordica charantia, L. medicinal plant growing wild in Trinidad and Tobago, Ind. Crops Prod., 2016, 95, 365-373.

41 M. B. Hossain, D. K. Rai, N. P. Brunton, A. B. Martin-Diana and C. Barry-Ryan, Characterization of phenolic composition in lamiaceae spices by LC-ESI-MS/MS, J. Agric. Food Chem., 2010, 58, 10576-10581.

42 N. Martins, L. Barros, C. Santos-Buelga, S. Silva, M. Henriques and I. C. F. R. Ferreira, Decoction, infusion and hydroalcoholic extract of cultivated thyme: Antioxidant and antibacterial activities, and phenolic characterisation, Food Chem., 2014, 167, 131-137.

43 P. Nocera, A. Lettieri and M. Catauro, A polyphenol complex from Thymus vulgaris L. plants cultivated in the Campania Region (Italy): New perspectives against neuroblastoma, J. Funct. Foods, 2016, 20, 253-266.

44 L. Barros, M. Dueñas, M. D. Inês, M. Sousa João, C. Santosbuelga and I. C. F. R. Ferreira, Phenolic profiles of cultivated, in vitro cultured and commercial samples of Melissa officinalis L. infusions, Food Chem., 2013, 136, 1-8.

45 H. Chen, Q. Zhang, X. Wang and Q. Wang, Qualitative analysis and simultaneous quantification of phenolic compounds in the aerial parts of salvia miltiorrhiza by HPLCDAD and ESI/MSn, Phytochem. Anal., 2011, 22, 247-257.

46 M. Ruan, Y. Li, X. Li, J. Luo and L. Kong, Qualitative and quantitative analysis of the major constituents in Chinese medicinal preparation Guan-Xin-Ning injection by HPLC-DAD-ESI-MSn, J. Pharm. Biomed. Anal., 2012, 59, 184-189.

47 G. Zeng, H. Xiao, J. Liu and X. Liang, Identification of phenolic constituents in Radix Salvia miltiorrhizae by liquid chromatography/electrospray ionization mass spectrometry, Rapid Commun. Mass Spectrom., 2006, 20, 499-506.

48 B. Hauck, J. A. Gallagher, S. M. Morris, D. Leemans and A. L. Winters, Soluble phenolic compounds in fresh and 
ensiled orchard grass (Dactylis glomerata, L.), a common species in permanent pastures with potential as a biomass feedstock, Agric. Food Chem., 2014, 62, 468-475.

49 F. Ferreres, B. M. Silva, P. B. Andrade, R. M. Seabra and M. A. Ferreira, Approach to the study of $C$-Glycosyl Flavones by Ion Trap HPLC-PAD-ESI/MS/MS: Application to seeds of Quince (Cydonia oblonga), Phytochem. Anal., 2003, 14, 352359.

50 M. Chaabi, N. Beghidja, S. Benayache and A. Lobstein, Activity-guided isolation of antioxidant principles from Limoniastrum feei (Girard) Batt., Z. Naturforsch., 2008, 63, 801-807.

51 M. N. Clifford, K. L. Johnston, S. Knight and N. Kuhnert, Hierarchical scheme for LC-MSn identification of chlorogenic acids, J. Agric. Food Chem., 2003, 51, 2900-2911.

52 M. N. Clifford, S. Knight and N. Kuhnert, Discriminating between the six isomers of dicaffeoylquinic acid by LC-MSn, J. Agric. Food Chem., 2005, 53, 3821-3832.

53 D. Campoccia, L. Montanaro and R. C. Arciola, A review of the biomaterials technologies for infection-resistant surfaces, Biomaterials, 2013, 34, 8533-8554.

54 T. P. Cushnie, V. E. S. Hamilton, D. G. Chapman, P. W. Taylor and A. J. Lamb, Aggregation of Staphylococcus aureus following treatment with the antibacterial flavonol galangin, J. Appl. Microbiol., 2007, 103, 1562-1567.

55 T. P. T. Cushnie and A. J. Lamb, Antimicrobial activity of flavonoids, Int. J. Antimicrob. Agents, 2005, 26, 343-356.

56 T. P. T. Cushnie and A. J. Lamb, Agents recent advances in understanding the antibacterial properties of flavonoids, Int. J. Antimicrob. Agents, 2011, 38, 99-107.

57 R. Hendra, S. Ahmad, A. Sukari and M. Y. Shukor, Flavonoid analyses and antimicrobial activity of various parts of Phaleria macrocarpa (Scheff.) Boerl Fruit, Int. J. Mol. Sci., 2011, 12, 3422-3431.

$58 \mathrm{M}$. Li and Z. Xu, Quercetin in a lotus leaves extract may be responsible for antibacterial activity, Arch. Pharmacal Res., 2008, 31, 640-644.

59 G. Mandalari, R. N. Bennett, G. Bisignano, D. Trombetta, A. Saija, C. B. Faulds and M. J. Gasson, Antimicrobial activity of flavonoids extracted from bergamot (Citrus bergamia, Risso) peel, a byproduct of the essential oil industry, J. Appl. Microbiol., 2007, 103, 2056-2064.

60 L. S. Teffo, M. A. Aderogba and J. N. Eloff, Antibacterial and antioxidant activities of four kaempferol methyl ethers isolated from Dodonaea viscosa, Jacq. var. angustifolia leaf extracts, S. Afr. J. Bot., 2010, 76, 25-29.

61 H. B. Nayaka, R. L. Londonkar, M. K. Umesh and A. Tukappa, Antibacterial attributes of apigenin, isolated from Portulaca oleracea L., Int. J. Bacteriol., 2014, 2014, 1-8.

62 Y. Sato, S. Suzaki, T. Nishikawa and M. Kihara, Phytochemical flavones isolated from Scutellaria barbata and antibacterial activity against methicillin-resistant Staphylococcus aureus, J. Ethnopharmacol., 2000, 72, 483488.

63 M. Sato, S. Fujiwara, H. Tsuchiya, T. Fujii, M. Iinuma, H. Tosa and Y. Ohkawa, Flavones with antibacterial activity against cariogenic bacteria, J. Ethnopharmacol., 1996, 54, 171-176.

64 L. E. Alcaraz, S. E. Blanco, O. N. Puig, F. Tomas and F. H. Ferretti, Antibacterial activity of flavonoids against methicillin-resistant Staphylococcus aureus strains, J. Theor. Biol., 2000, 205, 231-240.

65 W. F. Zheng, R. X. Tan, L. Yang and Z. L. Liu, Two Flavones from Artemisia giraldil and their antimicrobial activity, Planta Med., 1996, 62, 160-162.

66 S. G. Dastidar, A. Manna, K. A. Kumar, K. Mazumdar, N. K. Dutta, A. N. Chakrabarty, N. Motohashi and Y. Shirataki, Studies on the antibacterial potentiality of isoflavones, Int. J. Antimicrob. Agents, 2004, 23, 99-102.

67 A. P. Mukne, V. Viswanathan and A. G. Phadatare, Structure pre-requisites for isoflavones as effective antibacterial agents, Pharmacogn. Rev., 2011, 5, 13-19.

68 H. Hong, M. R. Landauer, M. A. Foriska and G. D. Ledney, Antibacterial activity of the soy isoflavone genistein, J. Basic Microbiol., 2006, 46, 329-335.

69 C. Morel, F. R. Stermitz, G. Tegos and K. Lewis, Isoflavones as potentiators of antibacterial activity, Agric. Food Chem., 2003, 51, 5677-5679.

70 M. Iinuma, H. Tsuchiya, M. Satot, J. Yokoyama, M. Ohyama, Y. Ohkawa, T. Tanaka, S. Fujiwarax and T. Fujiix, Flavanones with potent antibacterial activity against methicillin-resistant Staphylococcus aureus, J. Pharm. Pharmacol., 1994, 46, 892-895.

71 K. Simin, Z. Ali, S. M. Khaliq-uz-zaman and A. Viqar uddin, Structure and biological activity of a new rotenoid from Pongamia pinnata, Nat. Prod. Lett., 2010, 16, 351-357.

$72 \mathrm{H}$. $\mathrm{Xu}$ and S. F. Lee, Activity of plant flavonoids against antibiotic- resistant bacteria activity of plant flavonoids against Antibiotic- Resistant Bacteria, Phyther. Res., 2001, 15, 39-43.

73 M. Daglia, Polyphenols as antimicrobial agents, Curr. Opin. Biotechnol., 2012, 23, 174-181.

74 Y. Liu, N. Murakami, H. Ji, P. Abreu, S. Zhang, N. Murakami, H. Ji, P. Abreu, S. Z. Antimalarial, Y. Liu, N. Murakami, H. Ji, P. Abreu and S. Zhang, Antimalarial flavonol glycosides from Euphorbia hirta, Pharm. Biol., 2007, 45, 278-281.

75 I. Ben, E. Hadj, M. Chaouachi, R. Bahri and I. Chaieb, Chemical composition and antioxidant, antibacterial, allelopathic and insecticidal activities of essential oil of Thymus algeriensis Boiss. et Reut., Ind. Crops Prod, 2015, 77, 631-639.

76 F. Guesmi, M. Ben Farhat, M. Mejri and A. Landoulsi, Invitro assessment of antioxidant and antimicrobial activities of methanol extracts and essential oil of Thymus hirtus, sp. algeriensis, Lipids Health Dis., 2014, 13, 1-12.

77 N. Trabelsi, S. Oueslati, C. Henry-vitrac, P. Waffo-téguo, F. Medini, J. Mérillon, C. Abdelly and R. Ksouri, Phenolic contents and biological activities of Limoniastrum guyonianum fractions obtained by centrifugal partition chromatography, Ind. Crops Prod., 2013, 49, 740-746. 
78 A. Bouzidi, A. Benzarti, A. El Arem, A. Mahfoudhi, S. Hammami, M. Gorcii, M. Mastouri, A. N. Hellal and M. Zine, Chemical composition, antioxidant and anti- microbial effects of Tunisian Limoniastrum guyonianum, Durieu ex Boiss extracts, Pak, J. Pharm. Sci., 2016, 29, 1299-1305. 